\title{
Customer Satisfaction Is Effected By The Quality Of Service: A Case Study Indonesian
}

\author{
Rusdiyanto $^{\mathrm{a} *}$, WidiHidayat $^{\mathrm{b}} *$, YenniFayanni ${ }^{\mathrm{c} *}$, MuhammadAfifi Rahman $^{\mathrm{d} *}$, AmirulAffanRosyidi ${ }^{\mathrm{e}}$, Susan \\ NovitasariKhadijah $^{\mathrm{f}} *$, HendraIrawan $^{\mathrm{g}} *$, Muhammad Cahyani $^{\mathrm{h}} *$, DiniAyuPramitasari $^{\mathrm{i}}$, \\ ArifSyafi'urRochman ${ }^{j}$
}

a,b,c UniversitasAirlangga Indonesia, Jl. Airlangga No.4, Airlangga, Gubeng, Surabaya, East Java 60286 Indonesia

f,g,i,j*Universitas Gresik Indonesia, Jl. Arif Rahman Hakim No.2B, Gresik, City Gresik, East Java 60111 Indonesia

d*UniversitasWijaya Putra, Jl. Raya benowo 1-3 Benowo Surabaya, East Java 60227 Indonesia.

e*UniversitasBrawijaya Malang Indonesia, Jl. Jl. MT. Haryono No.165, Ketawanggede, Sub-District Lowokwaru, City Malang, East Java 65300 Indonesia.

$\mathrm{h}$ *PT. CahayaNegeriSemesta, Jl. Alambukit Sofa Blok E9 No.16 KembanganKebomas Gresik, East Java61124 Indonesia Email: ${ }^{\text {r }}$ rusdiyanto.se.m.ak-2017@feb.unair.ac.id, ${ }^{\mathrm{c}}$ yenni_fayanni-

2018@ feb.unair.ac.id, ${ }^{\mathrm{d}}$ afifisme@gmail.com, ${ }^{\mathrm{e}}$ Affanamirul@ gmail.com, ${ }^{\mathrm{f}}$ susan.novitasari@gmail.com, ${ }^{\mathrm{g}}$ hendra00046@ gmail.co m, ${ }^{\text {h }}$ cahyaniku@gmail.com, , idini.pramitasari@gmail.com, ${ }^{j}$ arifsyafiur@gmail.com,

Email CorespondingAuthor : ${ }^{b}$ widi-h@ feb.unair.ac.id

Article History: Received: 10 November 2020; Revised 12 January 2021 Accepted: 27 January 2021; Published online: 5 April 2021

\begin{abstract}
This study aims to determine and analyze the effect of service quality indicators in measurement using Tangible, Emphaty, Reliability, Responsiveness, and Assurance on Banking Customer Satisfaction in Indonesia.This research uses quantitative methods that are descriptive and tends to analyze using an inductive approach. This type of research uses Explanatary Research, the study population uses banking customers. The data collection method in this study is to spread questions with the right target, the questionnaire in this study has requirements that must be met: The questions are factual, the questions are opinion, the questions are self-perception. The findings in this study explain that service quality affects customer satisfaction, the results of statistical tests with $t$ test can be concluded that service quality has an influence on banking customer satisfaction.
\end{abstract}

Keywords: Service Quality, Customer Satisfaction

\section{Introduction}

The development of banks in Indonesia is experiencing very fierce competition, both in the field of products and services so that people have stepped again, not just saving but have become an investor community. The increasing intensity of competition and the number of competitors requires banks to offer a variety of products so that they are able to compete with other banks in providing the quality of their servants to customers.

There are various problems faced by the banking world in carrying out its main activities and in offering services from its products. In addition to the consideration of the high and low interest rates of each bank in providing loan capital, there are also problems regarding the availability of existing products at the bank, because not all banks can provide the same products that guarantee an increase in people's lives. There are also problems regarding the existing public facilities in a building of these banks. The problems that arise by the banking sector itself are regarding Human Resources who are less competent in serving customers.

Gap research of previous research in journals was used as a background foundation entitled "The effect of service quality and marketing mix on satisfaction (C.-M. Chen \& Liu, 2019; AAR Fernandes\&Solimun, 2018; Frank, Enkawa, Schvaneveldt, \&Herbas) Torrico, 2015; Muangmee, Meekaewkunchorn, Ratchanokpanyasupat, Bunuam, \&Suebsawat, 2020; Pradeep, Vadakepat\&Rajasenan, 2020; Puluhulawa, Machfudnurnajamuddin, Mallongi, \&Sufri, 2018; Srinita, 2018; Suvittawat, \&Bunliang, 2019; Syapsan, 2019; Wahyuni\&Rini, 2019). The results of this study indicate that there is an effect between service quality and marketing mix on patient satisfaction.

Meanwhile, the gap research in the second study entitled "Analysis of the effect of service quality and price on customer satisfaction (Elimam\&Dodin, 2001; Manikandan, Swaminathan, \&Khattri, 2012; Marhaeni, Fanani, Hartono, \&Nugroho, 2015; Vieira, Aguayo, \& Costa, 2006; Zarezadeh, Shafiei, \&Soltani, 2013). The findings show that service quality and price have an influence on customer satisfaction. 


\section{Literature Review And Hypothesis Development}

\subsection{Definition Of Customer}

A customer is a person or legal entity that has an account either a savings account or a loan with the bank $(\mathrm{N}$. Ameen et al., 2021; M. Chen, Chen, \&Zheng, 2021; Dogan\&Gurcan, 2021; Fagerstrøm, Eriksson, \& Sigurdsson , 2021; T. Fernandes\& Oliveira, 2021; Hendar, Sudarti, \&Rhemananda, 2021; Kwok, Hallstedt, \&Boeva, 2021; Ouankhamchan\&Fujinami, 2021; Sundararaj\&Rejeesh, 2021; S. Zhang, Tian, Guo, Shan , \& Liu, 2021). So that customers are people who usually relate to or become bank customers (Rianto, 2019) In other words, customers are parties or people who use and deliberately become trustworthy bank customers.

\subsection{Definition of Customer Satisfaction}

Satisfaction is a concept that is much broader than just an assessment of service quality (Barenji, Guo, Wang, Li, \& Rong, 2021; Cai, Wei, Gu, \& Wu, 2021; Feitó-Cespón, Costa, Pishvaee, \& Cespón-Castro , 2021; Hendar et al., 2021; Islam et al., 2021; Ramesh, Jaunky, Roopchund, \& Oodit, 2021), but also influenced by other factors that can be explained as follows: Quality of service or service, namely consumers will feel satisfied if they get good service or as expected, product quality, that is, consumers will feel satisfied if their results show that the product they are using is quality, price, which is a product that has the same quality but sets a relatively cheap price. give higher value to consumers, situation factors, namely the circumstances experienced by consumers, personal factors from consumers, namely consumer characteristics that include personal needs (Aasritha, Hemavathi, \& Suj atha, 2021; Cai, Wei, Wu, Gu, \& Zhang, 2021; Chakrabarti et al., 2021; Mert, Eskiocak, \& Öztürk, 2021; Sarucan, Emin Baysal, \& Engin, 2021; Zekhnini, Cherrafi, Bouhaddou, \& Benghabrit, 2021).

\subsection{Definition of Service Quality}

Services are one of the banking functions, therefore it should be done in a quality manner by the banks. Service quality is a word that for service providers is something that must be done well J. Supranto (2015: 226; Bi, Liu, Ren, \& Tan, 2021; Edan \& Mahmood, 2021; Keshavarzi, Toroghi Haghighat, \& Bohlouli, 2021; Kudva, Badsha, Sengupta, Khalil, \& Zomaya, 2021; Sang, 2021; Taheri, Chalmers, Wilson, \& Arshed, 2021; Wu \& Hsiao, 2021; Xia et al., 2021; Xu, Jiang, \& Li, 2021; Yang, Li, Trajanovski, Yahyapour, \& Fu, 2021).

\subsubsection{The relationship between service quality and satisfaction}

One of the reliable indicators that can influence consumers is service quality. Service quality itself is the overall perception of a company's service performance and changes frequently. Service quality as a global assessment or attitude regarding the superiority of a service (Akbar et al., 2020; A. Ameen, Al-Ali, Isaac, \& Mohammed, 2020; Park, Lee, \&Nicolau, 2020; Ramesh et al., 2021; Rodríguez, Villarreal, Valiño, \&Blozis, 2020; Wong et al., 2020).

Meanwhile, customer satisfaction is the response to this assessment. Service quality must begin with customer needs and end with the customer's perception. All parties who buy and consume services will give different assessments of service quality. This has a positive and significant impact on customer satisfaction (Antwi, Fan, Ihnatushchenko, Aboagye, \&Xu, 2020; Frauenholtz\& Mendenhall, 2020; Gong, Wang, \& Lee, 2020; Jeaheng, AlAnsi, \& Han, 2020 ;Jumaan, Hashim, \& Al-Ghazali, 2020; RodićLukić\&Lukić, 2020; Viotti, Sottimano, Converso, \&Guidetti, 2020; J. Zhang, Adhikari, Fahmy, \& Kang, 2020).

\subsection{Research Conceptual Framework}

The research conceptual framework is a relationship or link between one concept and another from the problem to be investigated. This conceptual framework is used to link or explain at length about a topic to be discussed. This framework is obtained from the concept of science / theory that is used as the basis for the research obtained in the literature review or if it may be said by the author, it is a summary of the literature review that is connected by a line according to the variables studied. 


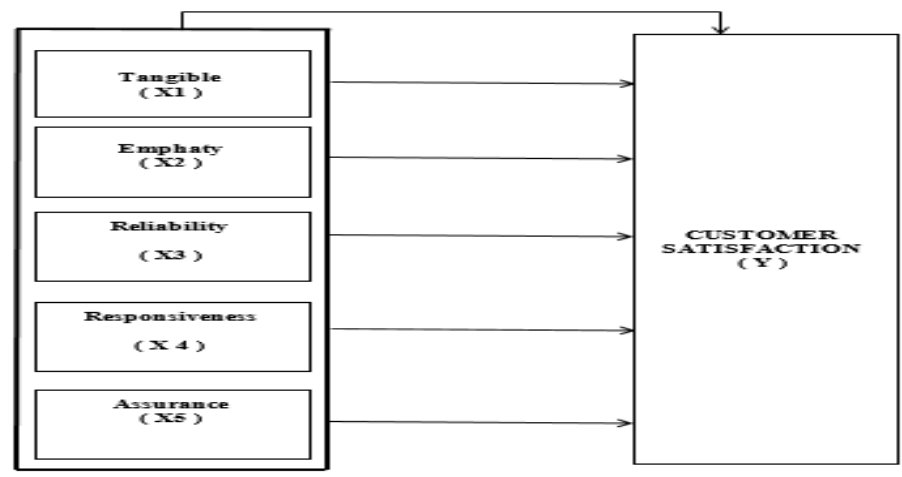

Figure 1: Research framework

\subsection{Research Hypothesis}

Hypothesis is the first step of research to prove a truth. The researcher makes a hypothesis for this problem as follows:

H1 : Service quality which includes Tangible (X1), Emphaty (X2), Reliability (X3), Responsiveness (X4), Assurance (X5) has a partial effect on customer satisfaction of BRI Unit Benjeng (Y)

H2 : Service quality which includes Tangible (X1), Emphaty (X2), Reliability (X3), Responsiveness (X4), Assurance (X5) has a simultaneous influence on customer satisfaction of BRI Unit Benjeng (Y)

\section{Research Methods}

\subsection{Types and Research Approaches}

This type of research is explanatory research. Explanatary Research is research that does not use statistics but through data collection, analysis, and interpretation. Quantitative research is descriptive research and tends to use analysis with an inductive approach. This type of research approach uses quantitative research(Juanamasta et al., 2019; Prabowo et al., 2020; Rusdiyanto, Agustia, et al., 2020; Rusdiyanto, Hidayat, et al., 2020; Syafii et al., 2020), (Juanamasta et al., 2019), (R. Rusdiyanto \& Narsa, 2019), (Gazali, Kusuma, Aina, Bustaram, Amar, et al., 2020), (Syafii et al., 2020), (Lamtiar et al., 2021), (Gazali, Kusuma, Aina, Bustaram, Risal, et al., 2020), (Rusdiyanto, Sawarjuwono, et al., 2020), (Shabbir et al., 2021), (Susanto et al., 2021), (Luwihono et al., 2021), (Rahayu et al., 2020), (Utari et al., 2020), (Prabowo et al., 2020), (Astanto et al., 2020), (H. T. Rusdiyanto et al., 2020), (Rusdiyanto, Sawarjuwono, et al., 2020), (HIDAYAT et al., 2020), (Rusdiyanto \& Narsa, 2020), (Ulum et al., 2020), (R. Rusdiyanto et al., 2019), (Hidayat et al., 2020), (Zainurrafiqi et al., 2020), (Zainurrafiqi et al., 2020), (Hadi Susanto et al., 2021), (Woro Utari et al., 2020), (Susanto et al., 2021), (Prasetyo et al., 2021). Quantitative research is research that does not use statistics but through data collection, analysis, and interpretation.

\subsection{Population, Sample, and Sampling Technique}

The population in this study is all customers who have an account / savings account of BRI Benjeng. This study took a sample of 60 people. Because based on the number of variables X + Y x $10(5+1 \times 10=60)$ As a general rule, a sample size of 30 to 500 can be effective depending on the sampling method used and the research questions used.

\subsection{Method of collecting data}

The questionnaire is a type of data collection method in this study, the method used to obtain accurate data is done by distributing questions with the right target, the results of distributing questionnaires are processed to be analyzed, this study targets the customers of BRI Bank Benjeng. The questionnaire in this study has requirements that must be met, namely: The questions to be given are factual, the questions to be given are opinions, the questions that will be given are self-perception.

The questions in the questionnaire are divided into six parts, six questionnaires consisting of 3 statement items using the Likert scale type using a scale of 5. The 5-point scale starts at a scale of 1 which means strongly disagree, whereas if the answer leads to the right it leads to agreement.

\subsection{Data analysis method}

\subsubsection{Descriptive Analysis Model}

Descriptive analysis is used to describe the independent variable $(\mathrm{X})$ which consists of service quality consisting of tangibles (X1), empathy (X2), reliability (X3), responsiveness (X4), assurance (X5) which affects 
the dependent variable (Y), namely customer satisfaction od BRI Benjeng. Descriptions of the influence of independent variables on the dependent variable, can be in the form of cross tabulation, histogram graphs and so on (Juanamasta et al., 2019; Rusdiyanto, Agustia, Soetedjo, \&Septiarini, 2020; Rusdiyanto, Hidayat, et al., 2020). This descriptive form was chosen according to the needs of the analysis so that the research objectives could be achieved.

\subsubsection{Multiple Regression Analysis Model}

Furthermore, to analyze whether there is a relationship between variables, Multiple Linear Regression Analysis is used. The regression analysis model according to Sugiyono (2015: 221) is as follows: A statistical count is called statistically significant if the statistical test value is in a critical area (the area where Ho is rejected). Conversely, it is not significant if the statistical test value is in the area where Ho is accepted. Multiple linear regression analysis is used to test the effect of independent variable indicators on variables with the following formulations:

$$
\mathrm{Y}=\mathrm{a}+\mathrm{b} 1 \mathrm{X} 1+\mathrm{b} 2 \mathrm{X} 2+\mathrm{b} 3 \mathrm{X} 3+\mathrm{b} 4 \mathrm{X} 4+\mathrm{b} 5 \mathrm{X} 5+\mathrm{e}
$$

\subsection{Hypothesis test}

\subsubsection{T test (partial)}

To test the research hypothesis, first know the basis for making decisions in the partial $t$ test. In this case there are two references that can be used as a basis for decision making, first by looking at the significance value (Sig) and second comparing the tcount value with the $t$ table.

\subsubsection{F Test (Simultaneous)}

There are two ways that are used as a reference or guideline for conducting hypothesis testing in the $\mathrm{F}$ test. The first is to compare the significance value (Sig.) Or the probability value of the ANOVA output. The second is to compare the F-count value with the F-table value

\subsubsection{Coefficient of Determination ( $R 2)$}

The coefficient of determination $\mathrm{R}^{2}$ in essence measures how far the model's ability to explain the dependent variables (Ghozali, 2016; 95). The coefficient of determination is zero and one. The small value of $\mathrm{R}^{2}$ means that the ability of the independent variables in explaining the variation of the dependent variable is very limited. A value close to one means that the independent variables provide almost all the information needed to predict the variation in the dependent variable.

\section{Results And Discussion}

\subsection{Multiple Linear Regression Test Results}

The process of processing data using multiple linear regression analysis carried out several stages to find the relationship between the independent and dependent variables. Based on the results of data processing using SPSS for Windows Realease version 22.0 software, a summary is obtained as in the following table.

Table 4 1: Multiple Linear Regression Test Results

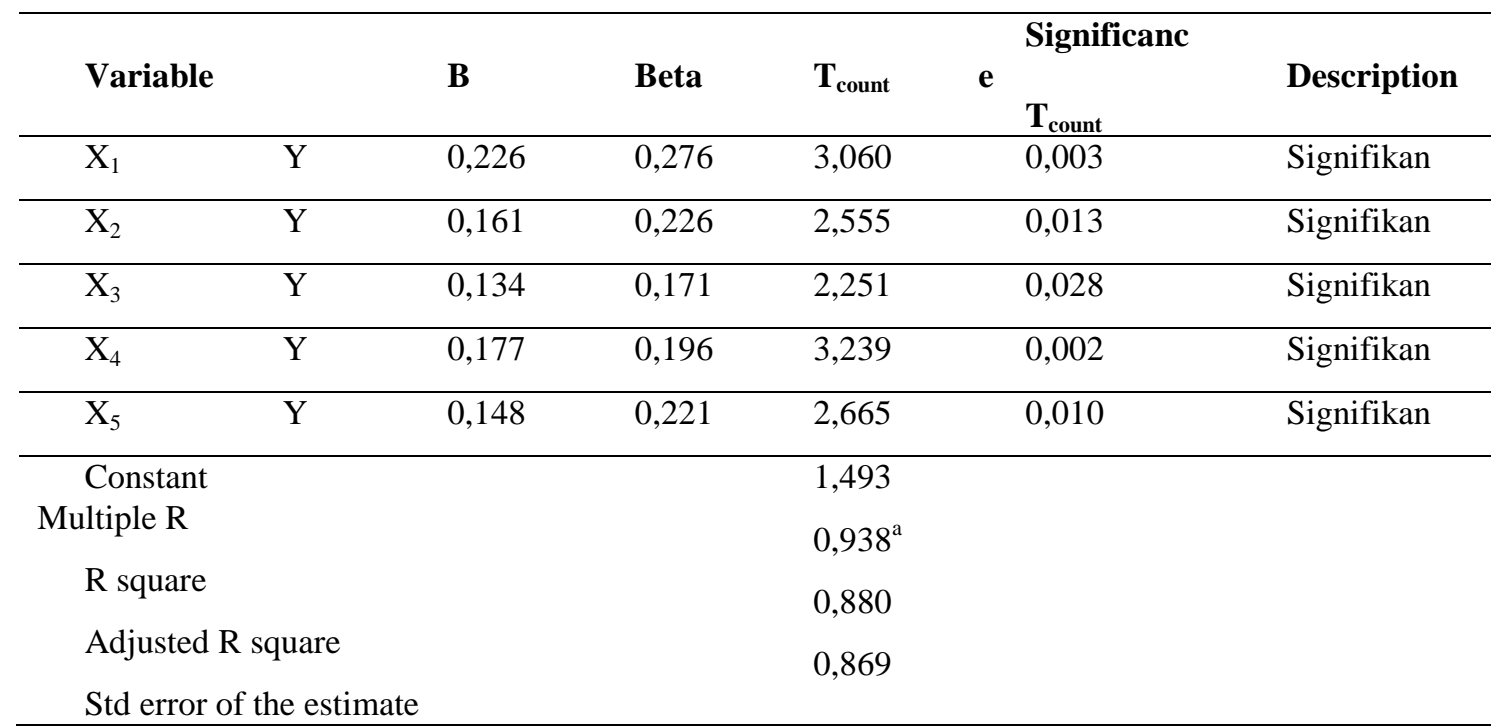




\subsection{Coefficient of Determination (R2)}

Table 4 2: Results of the Analysis of the Coefficient of Determination

\begin{tabular}{|c|c|c|c|}
\hline \multicolumn{4}{|c|}{ Model Summary } \\
\hline Model & $\mathrm{R}$ & $\begin{array}{l}\text { Adjusted } \\
\text { R Square Square }\end{array}$ & $\begin{array}{l}\text { R Std. Error of } \\
\text { the Estimate }\end{array}$ \\
\hline 1 & $.938^{\mathrm{a}}$ & .869 & .71575 \\
\hline
\end{tabular}

a. Predictors: (Constant), Emphaty (X5), Assurance(X4),
Responsiveness(X3), Reliability (X2), Tangibles (X1)

\section{b. Dependent Variable: Customer Satisfaction(Y)}

Based on the table above, the adjusted R Square is known to be 0.869. So it can be concluded that the independent variable $\mathrm{X}$ consisting of tangibles (X1), empathy (X2), reliability (X3), responsiveness (X4), assurance (X5) $86.9 \%$ is related to the dependent variable customer satisfaction of BRI Benjeng. Meanwhile, $13.1 \%$ is an error, which is related to other variables that were not examined in this study.

\subsection{Hypothesis Test}

The regression model that has been obtained is tested both simultaneously and partially. Simultaneous testing of the regression model is carried out using the F test or ANOVA and partial regression model testing is carried out by the t test.

\subsection{F test}

Simultaneous testing is carried out to show whether all the independent variables of service quality (X) consisting of physical evidence (X1) empathy (X2), reliability (X3), responsiveness (X4), and assurance (X5) have a significant effect simultaneously on the dependent variable customer satisfaction (Y). The $\mathrm{F}$ test is done by comparing the calculated $\mathrm{F}$ value with the $\mathrm{F}$ table value. All of these variables are tested simultaneously using the $\mathrm{F}$ test or ANOVA, if the calculated $\mathrm{F}$ value is greater than the F table, then Ho is rejected and accepts Ha. By using the help of SPSS software, the following F test results are obtained:

Table 4 3: Results of the F Test

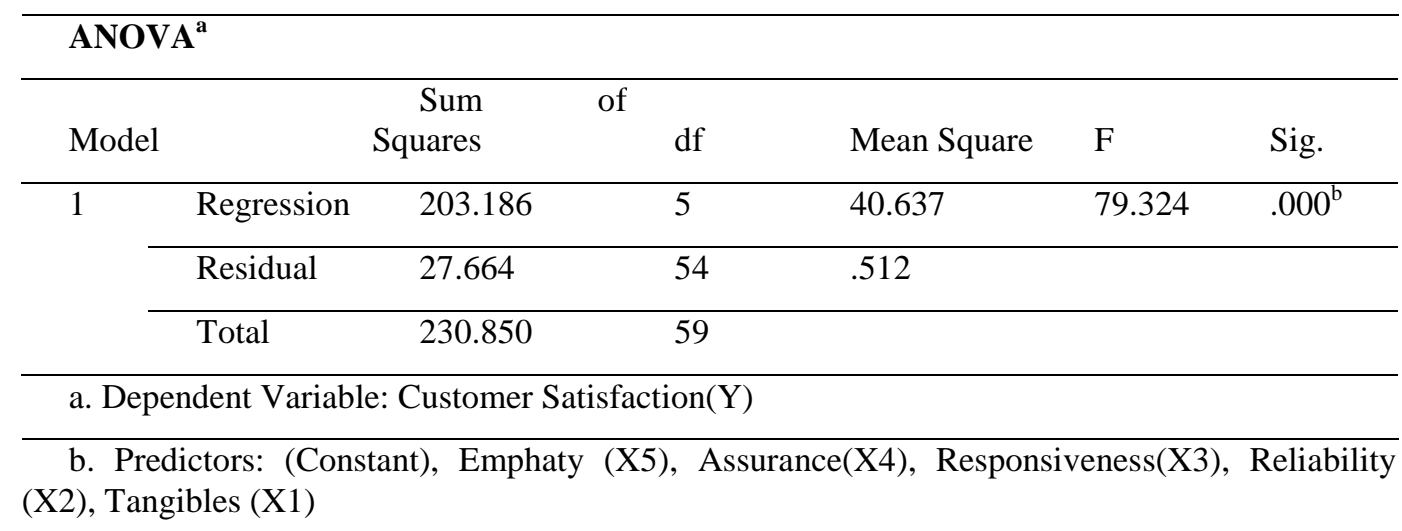

Based on table 4:23 above, it is known that the significance value is $0.000<\alpha=0.05$, thus it can be concluded that the quality of "service (X) which consists of physical evidence (X1) empathy (X2), reliability (X3), responsiveness (X4), and guarantee (X5) have a simultaneous influence on customer satisfaction of BRI Benjeng (Y).

\subsection{T test}

Partial regression model testing is used to determine whether each independent variable forming the regression model individually has a significant effect on variable $\mathrm{Y}$ or not. To test this relationship is to compare the value of 
$t_{\text {count }}$ with $t_{\text {table. }}$. The independent variable forming the regression model is said to have a significant effect if $t_{\text {count }}>$ $\mathrm{t}_{\text {table }}$ or significant $<\alpha=0.05$.

Partial effect of the independent variable Service Quality (X) which consists of physical evidence (X1) empathy (X2), reliability (X3), responsiveness (X4), and assurance (X5) on the dependent variable, namely customer satisfaction (Y) can be seen in the table the following:

Table 4 4: Results of the t test

\begin{tabular}{|c|c|c|c|c|c|c|}
\hline \multicolumn{7}{|c|}{ Coefficients $^{\mathrm{a}}$} \\
\hline \multirow{2}{*}{\multicolumn{2}{|c|}{ Model }} & Unstal & Coefficien & $\begin{array}{l}\text { Standardi } \\
\text { Coefficients }\end{array}$ & \multirow[b]{2}{*}{$\mathrm{t}$} & \multirow[b]{2}{*}{ Sig. } \\
\hline & & B & Std. Error & Beta & & \\
\hline \multirow[t]{6}{*}{1} & (Constant) & 1.493 & .597 & & 2.498 & .016 \\
\hline & Tangibles (X1) & .226 & .074 & .276 & 3.060 & .003 \\
\hline & Reliability (X2) & .161 & .063 & .226 & 2.555 & .013 \\
\hline & Responsiveness(X3) & .134 & .059 & .171 & 2.251 & .028 \\
\hline & Assurance(X4) & .177 & .055 & .196 & 3.239 & .002 \\
\hline & Emphaty (X5) & .148 & .056 & .221 & 2.665 & .010 \\
\hline
\end{tabular}

a. Dependent Variable: Customer Satisfaction(Y)

From the analysis of service quality data $(\mathrm{X})$ which consists of tangibles (X1), empathy (X2), reliability (X3), responsiveness (X4), assurance (X5) on customer satisfaction of BRI Benjeng (Y), the significance value is $0<\alpha$ $=0.05$. So it can be concluded that H1 is accepted, which means that there is a partial influence between service quality and customer satisfaction of BRI Benjeng.

\section{Discussion Of Research Results}

The results showed a simultaneous influence between service quality (X) which consists of tangibles (X1), empathy (X2), reliability (X3), responsiveness (X4), assurance (X5) on customer satisfaction of BRI Benjeng (Y). With the value of Fcount greater than Ftable (79.324> 3.09) and a significance of 0.000 , which means it is smaller than alpha $(\alpha)=0.05$. So it can be concluded that $\mathrm{H}_{0}$ is rejected and $\mathrm{Ha}$ is accepted, meaning that there is a simultaneous influence between service quality $(\mathrm{X})$ which consists of tangibles (X1), empathy (X2), reliability (X3), responsiveness (X4), assurance (X5) on customer satisfaction of BRI Benjeng (Y).

From the research results, multiple regression equations using standardized regression with the data used are interval data with measurements using the Likert scale. The Likert scale is used to measure attitudes, opinions and perceptions of a person or group. In standardized regression, the variable sizes have been equalized. The regression equation based on the table above is as follows:

$\mathrm{Y}=1,493+0,276 \mathrm{X}_{1}+0,226 \mathrm{X}_{2}+0,171 \mathrm{X}_{3}+0,196 \mathrm{X}_{4}+0,221 \mathrm{X}_{5}$

It shows that there is a partial influence of all the variables contained in the customer satisfaction variable (X) and the customer satisfaction variable of BRI Benjeng (Y). One variable in service quality increases, so BRI Benjeng (Y) customer satisfaction will also increase.

The regression model in this study has a determination coefficient (Adj. R2) of 0.869. The results of this coefficient explain that the contribution of the independent variable service quality $(\mathrm{X})$ consisting of tangibles (X1), empathy (X2), reliability (X3), responsiveness (X4), assurance (X5) can affect the dependent variable customer satisfaction BRI Benjeng (Y ) amounting to $86.9 \%$ and the remaining $13.1 \%$ is explained by other factors not discussed in this study. The significant effect of overall service quality on customer satisfaction of BRI Benjeng (Y), with the creation of customer satisfaction makes bank customers feel safe, comfortable and feel they have benefited from using services from banking.

\section{Conclusion}

Based on the research results found that service quality includes: Tangible, Emphaty, Reliability, Responsiveness, Assurance and Customer Satisfaction of BRI Unit Benjeng can be said to be good, and the five service quality variables simultaneously and partially affect customer satisfaction of BRI Unit Benjeng. For future research, BRI Unit Benjeng always maintains service quality, and pays attention to customers so that customers always feel that the Bank they use can always be trusted 


\section{References}

Astanto, D., Rusdiyanto, M. F., Khadijah, S. N., Rochman, A. S., \&Ilham, R. (2020). MACROECONOMIC IMPACT ON SHARE PRICES: EVIDENCE FROM INDONESIA. Solid State Technology, 63(6), 646-660.

Gazali, Kusuma, A., Aina, M., Bustaram, I., Amar, S. S., Rusdiyanto, Tjaraka, H., \&Panjilaksana, S. D. D. (2020). The Effect of Financial Performance on Stock Prices: a Case Study of Indonesian. Talent Development and Excellence, 12(1), 40074016. http://iratde.com/index.php/jtde/article/view/1351

Gazali, Kusuma, A., Aina, M., Bustaram, I., Risal, Z., Purwanto, Rusdiyanto, \&Tjaraka, H. (2020). Work Ethics of Madura Communities in Salt Business : A Case Study Indonesian. Talent Development and Excellence, 12(1), 3537-3549. http://iratde.com/index.php/jtde/article/view/1312

HadiSusanto, IndraPrasetyo, TrisaIndrawati, NabilahAliyyah, Rusdiyanto, HeruTjaraka, NawangKalbuana, ArifSyafi'urRochman, G. and Z. (2021). The impacts of earnings volatility, net income and comprehensive income on share Price: Evidence from Indonesia Stock Exchange. Accounting, 7(5), 1009-1016.

HIDAYAT, W., SOETEDJO, S., TJARAKA, H., SEPTIARINI, D. F., HERLI, M., ULUM, B., SYAFII, M., IRAWAN, H., \& RAHAYU, D. I. (2020). El efecto de la macroeconomía en los precios de lasacciones: estudio de casoindonesio. Revista ESPACIOS, 41(17).

Hidayat, W., Tjaraka, H., Fitrisia, D., Fayanni, Y., Utari, W., Indrawati, M., Susanto, H., Tjahjo, J. D. W., Mufarokhah, N., \&Elan, U. (2020). The Effect of Earning per Share, Debt to Equity Ratio and Return on Assets on Stock Prices: Case Study Indonesian. Academy of Entrepreneurship Journal, 26(2), 1-10.

Juanamasta, I. G., Wati, N. M. N., Hendrawati, E., Wahyuni, W., Pramudianti, M., Wisnujati, N. S., Setiawati, A. P., Susetyorini, S., Elan, U., Rusdiyanto, R., Astanto, D., Ulum, B., Khadijah, S. N., Trimarjono, A., Syafii, M., Mubarroq, A., Kristiningsih, K., Pratiwi, R. D., Veri, V., ... Umanailo, M. C. B. (2019). The role of customer service through customer relationship management $(\mathrm{Crm})$ to increase customer loyalty and good image. International Journal of Scientific and Technology Research, 8(10).

Lamtiar, S., Arnas, Y., Rusdiyanto, A. A., Kalbuana, N., Prasetyo, B., Kurnianto, B., Saputro, R., Kurniawati, Z., \&Utami, S. (2021). Liquidity Effect, Profitability Leverage to Company Value: A Case Study Indonesia. European Journal of Molecular \& Clinical Medicine, 7(11), 2800-2822.

Luwihono, A., Suherman, B., Sembiring, D., Rasyid, S., Kalbuana, N., Saputro, R., Prasetyo, B., Taryana, T., Suprihartini, Y., \&Asih, P. (2021). Macroeconomic effect on stock price: Evidence from Indonesia. Accounting, 7(5), 1189-1202.

Prabowo, B., Rochmatulaili, E., Rusdiyanto, \&Sulistyowati, E. (2020). Corporate governance and its impact in company's stock price: case study [Gobernabilidadcorporativa y suimpacto en el precio de lasacciones de lasempresas: Estudio de caso]. Utopia y Praxis Latinoamericana, 25(Extra10), 187-196. https://doi.org/10.5281/zenodo.4155459

Prasetyo, I., Aliyyah, N., Rusdiyanto, Tjaraka, H., Kalbuana, N., \&Rochman, A. S. (2021). VOCATIONAL TRAINING HAS AN INFLUENCE ON EMPLOYEE CAREER DEVELOPMENT : A CASE. Academy of Strategic Management Journal, 20(2), 1-14. https://www.abacademies.org/articles/Vocational-training-hasan-influence-on-employee-career-development-a-case-study-Indonesia-1939-6104-20-2-712.pdf

Rahayu, D. I., Ulum, B., Rusdiyanto, Syafii, M., Pramitasari, D. A., \&Tuharea, F. I. (2020). FUNDAMENTAL IMPACT ON SHARE PRICES: EVIDENCE FROM INDONESIA. PalArch's Journal of Archaeology of Egypt/ Egyptology, 17(6), 9090-9104. https://www.scopus.com/inward/record.uri?eid=2-s2.085099518109\&partnerID=40\&md5=1d2bda9716668cbcb2784e3a9a61df21

Rusdiyanto, Agustia, D., Soetedjo, S., \&Septiarini, D. F. (2020). The effect of cash turnover and receivable turnover on profitability $\mid$ El efecto de la rotación de efectivo y la rotación de cuentasporcobrar en la rentabilidad. Opcion, 36(Special Ed), 1417-1432.

Rusdiyanto, H. T., Mufarokhah, N., Al'asqolaini, M. Z., Musthofa, A. J., Aji, S., \&Zainab, A. R. (2020). Corporate Social Responsibility Practices in Islamic Studies in Indonesian. Journal of Talent Development and Excellence, 12(1), 3550-3565.

Rusdiyanto, Hidayat, W., Tjaraka, H., Septiarini, D. F., Fayanni, Y., Utari, W., Waras, Indrawati, M., Susanto, H., Tjahjo, J. D. W., Zainal, M., \&Imanawati, Z. (2020). The effect of earning per share, debt to equity ratio and return on assets on stock prices: Case study Indonesian. Academy of Entrepreneurship Journal, 26(2), 110.

Rusdiyanto, \&Narsa, I. M. (2020). The Effect of Company Size , Leverage and Return on Asset on Earnings Management : Case Study Indonesian. Espacios, 41(17), 25.

Rusdiyanto, R., Agustia, D., Soetedjo, S., Septiarini, D. F., Susetyorini, S., Elan, U., Syafii, M., Ulum, B., Suparman, P., \&Rahayu, D. I. (2019). Effects of Sales, Receivables Turnover, and Cash Flow on Liquidity.

Rusdiyanto, R., \&Narsa, I. M. (2019). THE EFFECTS OF EARNIGS VOLATILITY, NET INCOME AND COMPREHENSIVE INCOME ON STOCK PRICES ON BANKING COMPANIES ON THE INDONESIA STOCK EXCHANGE. International Review of Management and Marketing, 9(6). https://doi.org/10.32479/irmm.8640 
Rusdiyanto, Sawarjuwono, T., \&Tjaraka, H. (2020). Interpret The Shari' ah Accounting Practice In Indonesian. Talent Development and Excellence, 12(3), 2420-2433. http://iratde.com/index.php/jtde/article/view/1102

Shabbir, M. S., Mahmood, A., Setiawan, R., Nasirin, C., Rusdiyanto, R., Gazali, G., Arshad, M. A., Khan, S., \&Batool, F. (2021). Closed-loop supply chain network design with sustainability and resiliency criteria. Environmental Science and Pollution Research. https://doi.org/10.1007/s11356-021-12980-0

Susanto, H., Prasetyo, I., Indrawati, T., Aliyyah, N., Rusdiyanto, R., Tjaraka, H., Kalbuana, N., Rochman, A., Gazali, G., \&Zainurrafiqi, Z. (2021). The impacts of earnings volatility, net income and comprehensive income on share Price: Evidence from Indonesia Stock Exchange. Accounting, 7(5), 1009-1016.

Syafii, M., Ulum, B., Rusdiyanto, Suparman, P., Rahayu, D. I., \&Syasindy, N. B. (2020). The effect of financial performance on the company's share price: A case study Indonesian. European Journal of Molecular and Clinical Medicine, 7(8), 1055-1071. https://www.scopus.com/inward/record.uri?eid=2-s2.085098454552\&partnerID=40\&md5=10d4ddcf32dd4bf918ba3622c11e86dd

Ulum, B., Rusdiyanto, M. S., Rahayu, D. I., \&Pramitasarisari, D. A. (2020). PROFITABILITY IMPACT ON COMPANY SHARE PRICES: A CASE STUDY INDONESIAN. Solid State Technology, 63(6), 1672-1683.

Utari, W., Setiawati, R., Fauzia, N., Hidayat, W., Khadijah, S. N., Pramitasari, D. A., \&Irawan, H. (2020). The Effect of Work Discipline on the Performance of Employees in Compensation Mediation : A Case Study Indonesia. 17(9), 1056-1073.

Zainurrafiqi, Gazali, N. Q. and N. H. (2020). The Effect Of Organization Learning Capability And Organizational Innovation On Competitive Advantage And Business Performance. Russian Journal of Agricultural and Socio-Economic Sciences (RJOAS), 3(99), 9-17. https://doi.org/10.18551/rjoas.2020-03.02

Zainurrafiqi, RiaRacawati, Devi Lestari PramitaPutri , EnzaResdiana, EndangWidyastuti, QaiyimAsy’ari , Rusdiyanto, W. H. (2020). The Determinants And Consequents Of Competitive Advantage Based Of Local Wisdom At The Micro, Small, And Medium Enterprise : Evidence From Indonesia. Solid State Technology, 63(6), 1604-1620. 